\title{
A Cross-Linguistic Approach to Analysing Cohesive Devices in Expository Writing by Asian EFL Teachers
}

\author{
BUI PHU HUNG \\ University of Economics Ho Chi Minh City, \\ Vietnam \\ hungbp@ueh.edu.vn \\ NGUYEN NHAT QUANG \\ HQT Education, Ho Chi Minh City, \\ Vietnam \\ LOC TAN NGUYEN \\ University of Economics Ho Chi Minh City, \\ Vietnam \\ NGUYEN THI VIET \\ Hong Duc University \\ Vietnam
}

\begin{abstract}
Recent research has shown that cohesive devices contribute substantially to writing quality and reveal L2 writers' information, such as first or native language. This quantitative study adopted a cross-linguistic approach to investigating the use of cohesive devices in expository writing by Asian EFL teachers compared to native English teachers. The study involved 80 participants from three different L1 backgrounds, including 28 Vietnamese, 26 Filipino, and 26 native English teachers. The Vietnamese and Filipino teachers were at a comparable level of English proficiency. Around 800 words were randomly selected from each participant's reports for analysis. Results from One-Way ANOVA showed that the Vietnamese and Filipino teachers used a similar pattern of cohesion with lexical cohesion being used most frequently, followed by reference and conjunction. In contrast, the cohesive devices used by the native English teachers dispersed more widely across five main categories. The results further showed that the native English teachers used more cohesive devices in writing than the Vietnamese and Filipino teachers separately. Results from the Independent-Samples T-test showed omission and redundancy to be the two most common error types by both the Vietnamese and Filipino teachers. The study has implications for L2 writing and pedagogy.
\end{abstract}

Keywords: L2 writing; cohesive devices; error analysis; discourse analysis; cohesion error patterns

\section{INTRODUCTION}

\section{THE RATIONALE}

For many EFL learners, writing appears to be one of the most challenging skills to achieve (Nunan, 1989). Recent statistics by the International English Language Testing System (IELTS) revealed that Asian EFL test takers' writing scores are the lowest of all the four major language skills (IELTS, 2019). In writing, research shows that cohesion helps build the text structure in which text elements are interconnected (Halliday \& Metthiessen, 2014; Taboada, 2004; Yule, 2008). Thus, cohesion contributes substantially to discourse unity (Tanskanen, 2006). Cohesive devices which "interact closely and simultaneously to provide textuality" (Collins \& Hollo, 2010, p. 175) are significant in number and complex in types. One distinct characteristic of a text is its cohesive semantic unit (Halliday \& Hasan, 1976). However, research has shown that central to Asian EFL students' academic writing problems is the lack of text cohesion (Lake, 2004). Such a problem with writing cohesion amongst Asian EFL 
learners may be attributed to their insufficient exposure to the English language, lack of practice, teaching and learning contexts, and word-by-word translation (Hammad, 2016). As Farsani et al. (2019) hold, analysis of EFL students' written texts provide useful insights into the learners' language competencies, motivation, and self-efficacy, which in turn provide implications for writing pedagogy (Yin, 2015).

Within the Vietnamese EFL context, learners mainly focus on accuracy in writing but less on self-efficacy, communication skills, and critical thinking skills. Additionally, Vietnamese EFL teachers consider English as an international language and so classroom tasks are heavy per se (Le \& Phan, 2013). This follows that teachers are less likely to be able to foster learners' communication ability. Research shows that Vietnamese EFL teachers spend most class time helping students complete exercises in the prescribed textbooks (Hoa, 2020) and many teachers did not take their students' feelings and expectations into consideration (Tomlinson \& Dat, 2004). To enhance Vietnamese EFL learners' language competencies, the Vietnamese government has decided to involve foreign teachers in the national education system, including native English speakers and Filipino teachers (MOET, 2008). In the EFL education sector of Vietnam, whether Filipino teachers are well-qualified to teach English is a controversial issue. Given writing as part of the communication process, it is necessary to look into how Vietnamese, Filipino, and native English teachers holding a teaching position in Vietnam use cohesive devices in their writing.

\section{COHESION AND COHERENCE}

A text is a beyond-sentence-level means of communication in which writers synthesise the event, personal knowledge, culture, and context to make meaning (Halliday \& Matthiessen, 2014; Koshik, 1999). A text is built up with sentences being woven into interdependent paragraphs to form a unified unit (Reynolds, 2001; Cox et al., 1990) in which cohesion and coherence together create the connectedness of the text (Halliday \& Matthiessen, 2014). The tentative boundary between cohesion and coherence may make text analysts find it hard to focus on analysing only one element in a text.

The notions of coherence and cohesion are interrelated. According to Sanders and Maat (2006) and Malmkjaer (2001), cohesion refers to the use of cohesive devices to make a text a unified structure. Halliday and Matthiessen (2014) provide a list of cohesive devices (see Table 1) each of which has particular functions in a text, making different parts of a text interdependent. Coherence, on the other hand, refers to the reader's understanding of a text in which the writer codes his or her knowledge (Sanders \& Maat, 2006). In other words, while cohesion shows the writer's writing skills (Reynolds, 2001), style, and proficiency level (Normant, 2002; Reynolds, 2001), coherence is a "result of interaction between the reader's world and the text, with the reader making plausible interpretations" (Malmkjaer, 2001, p. 549).

Although some researchers consider cohesion and coherence as two interfaced elements integrated into a text, Castro (2004) and Oller and Jonz (1994) argued that cohesion and coherence might not co-exist within one particular text. Such an argument can be illustrated through examples 1 and 2 below.

Example 1:

"My car is black. Black English was a controversial subject most people have retired. To retire means to put new tires on a vehicle. Some vehicles, such as hovercrafts, have no wheels. Wheels go round." (Enkvist, 1990, p. 12)

Example 2:

"Someone came my house. Says give me money. Husband take gun shoot. Go outside die. Call police. Emergency 911. Policemen come. Take black man go hospital die.” (Koshik, 1999, p. 11) 
In example 1, although the writer used several cohesive devices such as repeating the word black, retire, vehicle, and wheel, the text does not create comprehensibility since the sentences together do not form unity. However, example 2 demonstrates that the reader is still able to make sense of the text even though the writer did not use any cohesive devices to link the sentences. Thus, cohesion but not coherence exists in example 1 and coherence but not cohesion exists in example 2.

While cohesion has been researched in the field of structural linguistics, coherence is situated as a concept in linguistics, discourse psychology, and cognition science (Sanders \& Maat, 2006). Within the scope of this study, cohesive devices are considered as indications of cohesion required in a text. The study adopted the taxonomy proposed by Halliday and Matthiessen (2014) to analyse the use of cohesive devices in the participants' report writing.

\section{TAXONOMY FOR ANALYSING COHESIVE DEVICES}

This study applied the taxonomy proposed by Halliday and Matthiessen (2014) as it is updated. The definitions and examples illustrating this taxonomy are strictly based on this taxonomy, with five main types of cohesive devices: reference, substitution, ellipsis, conjuncts, and lexical cohesion (see Table 1).

Reference is defined as the use of a word to refer to a preceding or following item. Typically, reference has two main sub-types: endophora and exophora. Endophora, which may take the form of anaphora (a preceding item) or cataphora (an item that follows), refers to an item within a text. This means that the interlocutor does not need to rely on the situation to make meaning of the text. In contrast, exophora refers to an item outside the text. For instance, a person may point to an object and say this or it as in "I like $\underline{i t}$ ". In this case, it is not possible for the reader or listener to understand the utterance without referring to the situation. In writing, only endophoric reference indicates text cohesion, of which anaphora makes up the majority.

Cohesive reference can be further divided into three main types: personal, demonstrative, and comparative. Personal reference is defined as the use of personal pronouns and possessive determiners to make a text cohesive. For example, in the sentence "The man is painting his house", the possessive determiner his is used to indicate the relationship between the man and the house. Demonstrative reference is the use of specific demonstratives, namely this, that, these, those, here, and there, and non-specific demonstratives, namely it and the to refer to someone or something that exists in a text or an environment. Both personal and demonstrative references establish the relation of co-reference. Comparative reference is referred to as a relation of contrast. The use of post-deictic adjectives (e.g., equal and same), adverbials (e.g., likewise, differently, and as), and comparative adjectives (e.g., better, less, and such) are examples of comparative reference.

Substitution is a grammatical relation in which one linguistic item substitutes a more complex one. Readers can understand the substitution by referring to the original item. Substitution is of three main types: nominal, verbal, and clausal. In nominal substitution, a noun or the head noun in a noun phrase can be replaced by one (for singular nouns) or ones (for plural nouns). The writer can also replace an entire noun phrase by using the same as in "Liz has a new car, and Maria will have the same.". In verbal substitution, the verb do is used to substitute the lexical verb or an entire verb phrase. Like substitution, ellipsis consists of three types, including nominal, verbal, and clausal. However, the distinction is that ellipsis involves omission rather than substitution. 
TABLE 1. Taxonomy of cohesive devices

\begin{tabular}{|c|c|c|c|}
\hline Type & Sub-type & & Definition and example \\
\hline \multirow[t]{3}{*}{ Reference } & Exophora & & $\begin{array}{l}\text { Reference item is deictic and connects the text to the } \\
\text { environment, e.g., this, that, here, there... }\end{array}$ \\
\hline & \multirow[t]{2}{*}{ Endophora } & Anaphora & $\begin{array}{l}\text { Reference points backward to an antecedent in the text, e.g., } \\
\text { The teacher is off today because he is sick. }\end{array}$ \\
\hline & & Cataphora & $\begin{array}{l}\text { Reference points forwards to a following element in the text, } \\
\text { e.g., I take her to school every day, but my daughter is closer } \\
\text { to her mother. }\end{array}$ \\
\hline \multirow[t]{3}{*}{ Substitution } & Nominal & & $\begin{array}{l}\text { Substitution of a noun or noun phrase by one, or ones, e.g., } \\
\text { This cake is awful. Give me another one. }\end{array}$ \\
\hline & Verbal & & $\begin{array}{l}\text { The use of auxiliaries to substitute a lexical verb or a verb } \\
\text { phrase, e.g. Did you enjoy the party? - Yes, I did. }\end{array}$ \\
\hline & Clausal & & $\begin{array}{l}\text { The use of so and/or not in a positive or negative clause } \\
\text { respectively to substitute a presumed clause, e.g., Do you } \\
\text { think the business will be better?- I think so. }\end{array}$ \\
\hline \multirow[t]{3}{*}{ Ellipsis } & Nominal & & $\begin{array}{l}\text { The noun or noun phrase is omitted in the text, e.g., Which } \\
\text { bag will you take? - I will take the smallest. }\end{array}$ \\
\hline & Verbal & & $\begin{array}{l}\text { The lexical verb or verb phrase is left out in the text, e.g., Will } \\
\text { you go to school today? - No, tomorrow. }\end{array}$ \\
\hline & Clausal & & $\begin{array}{l}\text { A large part or the whole clause is omitted, e.g., Where did } \\
\text { you keep your pencil case? - In the drawer. }\end{array}$ \\
\hline \multirow[t]{4}{*}{ Conjunction } & Additive & & $\begin{array}{l}\text { Addition of extra information showing afterthoughts, } \\
\text { examples, e.g., moreover, for example }\end{array}$ \\
\hline & Adversative & & $\begin{array}{l}\text { Introduction of a contrastive relationship between sentences, } \\
\text { e.g., however, on the other hand }\end{array}$ \\
\hline & Causal & & $\begin{array}{l}\text { Showing a cause-effect relationship between sentences, e.g., } \\
\text { as a result, therefore, otherwise }\end{array}$ \\
\hline & Temporal & & $\begin{array}{l}\text { Showing sequence of events between sentences, e.g., } \\
\text { afterward, meanwhile, finally }\end{array}$ \\
\hline \multirow[t]{4}{*}{$\begin{array}{l}\text { Lexical } \\
\text { cohesion }\end{array}$} & Synonymy & & $\begin{array}{l}\text { Use of synonyms or near-synonyms in the following } \\
\text { sentences, e.g. }\end{array}$ \\
\hline & Repetition & & Repetition of the same word in the following sentences, e.g. \\
\hline & Hyponymy & & $\begin{array}{l}\text { Replacement of a word with another word which is } \\
\text { semantically superclass, sub-class, or another class at the } \\
\text { same level of classification, e.g., John and his wife went to the } \\
\text { supermarket and bought meat, fruit, and vegetables. They } \\
\text { need food for the party. }\end{array}$ \\
\hline & Meronymy & & $\begin{array}{l}\text { A lexical cohesion by using a word as a part of an entity, e.g., } \\
\text { In the morning, Maria often goes to the garden and takes care } \\
\text { of roses and orchids. }\end{array}$ \\
\hline
\end{tabular}

Conjunction refers to the use of adverb conjuncts or connectives to connect sentences. There are four types of adverb conjuncts: additive, adversative, causal, and temporal. Additive conjuncts are used to add information or an afterthought as in "Teachers generally think doing homework is the right way of improving students' competence. Besides, intensive reading is required." Adversative conjuncts show contrasts between sentences as in "John felt exhausted. However, he tried to concentrate on his work." Causal conjuncts are used to illustrate a causeeffect relationship between sentences as in "There is no easy road to success. Individuals usually encounter obstacles. Therefore, we must act together." Temporal conjuncts indicate a sequence of actions, events, or phenomena as in "My wife cooked a lot of food. Then, she set the table for dinner."

Lexical cohesion is defined as the repetition of words in a previous sentence or the use of synonyms or words of the same class/category. Lexical cohesion is of four types: synonymy, repetition, hyponymy, and meronymy. Synonymy refers to the use of a synonym or near- 
synonym in a successive sentence as in "The price of gasoline increased significantly in the last two years. The rise had adverse effects on the economy.". In repetition, a word or phrase is repeated in the sentence that follows as in "Of all kinds of flowers, I like roses the most. The fragrance of roses always makes me feel relaxed.". Hyponymy is defined as the semantic replacement of a word with another word which is the superclass, subclass, or another class at the same level of classification as in "John and his wife went to the supermarket and bought meat, fruit, and vegetables. They need food for the party.". In this example, the word food is a broad term that includes meat, fruit, and vegetables, which have been mentioned before. In meronymy, a word is used as part of an entity as in "In the morning, Maria often goes to the garden and takes care of roses and orchids.". In this sentence, the words roses and orchids are parts of the garden.

\section{PREVIOUS STUDIES}

The lexicogrammatical system of cohesion outlined by Halliday and Hasan (1976) has motivated several studies on students' use of English cohesive devices in different contexts. These studies gave implications for discourse analysis and teaching English as a second/foreign language. Many studies attempted to examine the relationship between text cohesion and writing quality and yielded controversial findings. Todd et al. (2007), for example, conducted a study on postgraduate students' essays at a Thai university. The researchers concluded a weak relationship between the quality of writing and the use of connectives based on the tutors' comments. In contrast, research by Liu and Braine (2005) showed that first-year Chinese tertiary EFL students were generally incapable of using cohesive devices properly in their argumentative essays. The results demonstrated a strong relationship between text connectedness and writing quality. The inconsistency in the results of these two studies was probably due to the differences in data analysis and scopes of the studies. Liu and Braine (2005) mainly based on the number of cohesive devices used in essays that varied in length and did not investigate the students' lexical resources to make such a conclusion.

Two other studies involved participants from different levels of language proficiency. In Chiang's (1999) research, 172 essays by college students of beginning and intermediate levels were analysed. The results showed that the more cohesive devices the students used in their compositions, the higher they scored. Zhang (2000) analysed 107 expository essays by Chinese students. The study showed no significant correlation between indices of cohesion and writing quality. The relationship between cohesion and writing quality was inconclusive partly because the researchers analysed the texts by learners of different proficiency levels without a control group of native speakers. Mackey and Gass (2005) believe that the involvement of native speakers as participants in research on second language analysis helps interpret language production more insightfully and reliably due to the nature of their language use.

In terms of cohesive devices used in L2 writing, several studies have been carried out. Zhang (2000), for instance, found that Chinese students used a range of cohesive devices in their essay writing, with lexical cohesion being used most frequently, followed by conjunctions and references. Similarly, research by Rahman (2013) showed that lexical cohesion was most frequently employed by Omani EFL students, followed by references and conjunctions but native speakers used substitution and ellipsis more frequently. It is noteworthy that the contexts in which the two studies were conducted may account for the inconsistency in their findings.

Besides, several studies have looked into the relationship between students' proficiency levels and text cohesion. Crossley and McNamara (2012) analysed EFL students' use of cohesion and linguistic sophistication in 514 essays. The results showed that proficiency levels were not directly related to the students' ability to achieve text cohesion in writing. Al-Jarf (2001) analysed cohesive devices in academic writing by 59 EFL students at an Arabian 
university. The researcher argued that the students' awareness of syntactic and semantic features of cohesive devices rather than proficiency levels helped constitute text cohesion in writing.

Research has also examined cohesion problems in EFL learners' essays. For Chinese tertiary EFL students, Zhang's (2000) study showed that they used limited lexical cohesion, vague references, and repeated and misused conjunctions. However, Ong (2011) found that the most common problem amongst Chinese EFL students was the use of references. Similar results were found in Rahman's (2013) research. In this study, Rahman analysed descriptive essays by Omani students and concluded that the students overused references. Overall, these studies showed some alignment in their findings but did not look at whether the participants' cohesion errors were correlated with the frequency of that type of cohesion in use. This is important because the tendency of a higher frequency of one type of cohesion is likely to cause a higher percentage of errors.

Another strand of research investigated L1 interference in L2 learners' use of cohesive devices. Kang (2005) conducted a quantitative study on comparing discourse strategies for developing cohesion in narratives written in Korean and English. The study involved Korean EFL learners and native English speakers from the USA. The results showed that the Korean learners adopted Korean linguistic strategies in their texts written in English. In particular, demonstrative references and repetition were evident. A cross-linguistic study should involve heterogeneous L2 groups for comparisons (Jarvis, 2000) to obtain insights into learners' L1 interference in their use of L2.

\section{RESEARCH AIMS AND QUESTIONS}

Employing the taxonomy by Halliday and Hasan (1976), previous research has sought to describe and understand cohesion in EFL learners' writing in different contexts by analysing their descriptive and argumentative essays. Hitherto, there has been limited research on this topic within the Vietnamese EFL context. In addition, no published research has compared the use of cohesive devices in compositions by teachers of different L1 backgrounds in Asia. To address these research gaps, the current study examines cohesion in teaching reports by Vietnamese and Filipino EFL teachers. Using a cross-linguistic approach to analyse the use of cohesive indices in expository writing by Vietnamese and Filipino EFL teachers compared to those by native English teachers, the study seeks to answer the following questions:

1. How frequently do Vietnamese and Filipino EFL teachers use each type of cohesive device in writing compared to native English speakers?

2. What types of cohesion errors do Vietnamese and Filipino EFL teachers make in writing?

\section{RESEARCH METHODS}

\section{RESEARCH APPROACH AND DESIGN}

The study adopted a quantitative approach to analysing and comparing the indices of cohesion used in monthly teaching reports by Vietnamese and Filipino EFL teachers and native English speakers. It applied the methodological framework by Jarvis (2000) which describes the six main factors: (1) users' target language proficiency, (2) users' age, (3) users' education level, (4) intra-L1-group homogeneity, (5) inter-L1-group heterogeneity, and (6) text type. 


\section{RESEARCH SETTING AND PARTICIPANTS}

The study was carried out at five different English centres in Ho Chi Minh City, Vietnam with the participation of 80 EFL teachers from three different L1 backgrounds. They included Vietnamese $(n=28)$, Filipino $(n=26)$, and native English speakers $(n=26)$. All the teacher participants had an MA degree and TESOL certificates, aged from 30 to 40. The teachers' teaching experience ranged from four to eight years. The Vietnamese and Filipino teachers' English proficiency was at the $\mathrm{C} 1$ level of the Common European Framework References (CEFR). All the participants had taken academic writing courses as recorded in their academic transcripts. For ethical issues, all the participants and their workplaces were kept anonymous.

\section{DATA COLLECTION AND ANALYSIS}

Data were collected from the participants' monthly teaching reports. On average, around 800 words from each participant's reports were randomly selected for analysis. According to the report guidelines, the teachers were expected to demonstrate critical thinking in writing their monthly reports, compare and analyse different points of view, and suggest solutions to contextual problems if any. The teachers were encouraged to use a diversity of cohesive devices in writing their reports as well.

There were three main phases in the process of data analysis. First, all the teachers' monthly reports were scrutinised to identify instances and types of cohesive devices used in each report, followed by classifying these devices in accordance with the taxonomy. Second, the teachers' problems with their use of cohesive devices were identified and analysed. Finally, the data was sent to SPSS 25 package (IBM Corporation) for analysis. One-Way ANOVA was conducted to examine the Vietnamese and Filipino teachers' use of cohesive devices compared to those by the native English teachers. The Independent-Samples T-test was carried out to compare and contrast the errors made by the Vietnamese and Filipino teachers. Statistics achieved were mainly rounded to two decimal places. Based on previous research by Ong (2011) and Rahman (2013), cohesion errors were classified into four main groups: misuse, redundancy, omission, and overabundance, as shown in Table 2.

TABLE 2. Taxonomy for cohesion errors

\begin{tabular}{ll}
\hline Error & Definition \\
\hline Misuse & A cohesive device is used in place of a correct one. The one in use is incorrect. \\
Redundancy & A cohesive device in use is unnecessary or redundant. \\
Omission & A necessary cohesive device is absent in the text. \\
Overabundance & A cohesive device is used repeatedly, but other words can replace them. The \\
& replacement is still correct.
\end{tabular}

\section{RESULTS}

RESEARCH QUESTION 1: HOW FREQUENTLY DO VIETNAMESE AND FILIPINO EFL TEACHERS USE EACH TYPE OF COHESIVE DEVICES IN THEIR WRITTEN REPORTS COMPARED TO NATIVE ENGLISH TEACHERS?

Table 3 displays the descriptive statistics on the use of cohesive devices in written reports by the Vietnamese, Filipino, and native English teachers. Overall, the Vietnamese and Filipino EFL teachers used a similar cohesion pattern in their report writing. An average Vietnamese EFL teacher used more cohesive devices than the Filipino counterpart in terms of reference (R), ellipsis (E), and lexical cohesion (L). However, the cohesive indices of substitution (S) and conjunction (C) used by the Filipino EFL teachers outnumbered those by the Vietnamese ones. The native English teachers used more cohesive instances in all the observed categories. 
While the Vietnamese and Filipino teachers used lexical cohesion, conjunction, and reference most frequently, the cohesive devices used by the native English teachers dispersed across the five main sub-classes.

TABLE 3. Types of cohesive devices used by teachers

\begin{tabular}{|c|c|c|c|c|c|c|c|c|c|}
\hline & & \multirow[t]{2}{*}{$\mathbf{N}$} & \multirow[t]{2}{*}{ Mean } & \multirow[t]{2}{*}{ SD } & \multirow{2}{*}{$\begin{array}{c}\text { SD } \\
\text { Error }\end{array}$} & \multicolumn{2}{|c|}{ 95\% Confidence Interval } & \multirow[t]{2}{*}{ Minimum } & \multirow{2}{*}{$\begin{array}{c}\text { Maximu } \\
\text { m }\end{array}$} \\
\hline & & & & & & Lower Bound & Upper Bound & & \\
\hline \multirow[t]{4}{*}{$\mathrm{R}$} & Vietnamese teachers & 28 & 17.18 & 1.19 & .22 & 16.72 & 17.64 & 15.00 & 19.00 \\
\hline & Filipino teachers & 26 & 16.35 & .94 & .18 & 15.97 & 16.72 & 14.00 & 18.00 \\
\hline & Native English teachers & 26 & 21.00 & 1.13 & .22 & 20.54 & 21.46 & 19.00 & 23.00 \\
\hline & Total & 80 & 18.15 & 2.29 & .26 & 17.64 & 18.66 & 14.00 & 23.00 \\
\hline \multirow[t]{4}{*}{$\mathrm{S}$} & Vietnamese teachers & 28 & 8.82 & .98 & .19 & 8.44 & 9.20 & 7.00 & 10.00 \\
\hline & Filipino teachers & 26 & 9.31 & .97 & .19 & 8.92 & 9.70 & 8.00 & 11.00 \\
\hline & Native English teachers & 26 & 11.42 & .90 & .18 & 11.06 & 11.79 & 10.00 & 13.00 \\
\hline & Total & 80 & 9.83 & 1.47 & .16 & 9.50 & 10.15 & 7.00 & 13.00 \\
\hline \multirow[t]{4}{*}{$\mathrm{E}$} & Vietnamese teachers & 28 & 5.18 & .72 & .14 & 4.90 & 5.46 & 4.00 & 7.00 \\
\hline & Filipino teachers & 26 & 3.92 & .98 & .19 & 3.53 & 4.32 & 3.00 & 6.00 \\
\hline & Native English teachers & 26 & 8.58 & .99 & .19 & 8.18 & 8.98 & 7.00 & 10.00 \\
\hline & Total & 80 & 5.88 & 2.15 & .24 & 5.40 & 6.35 & 3.00 & 10.00 \\
\hline \multirow[t]{4}{*}{$\mathrm{C}$} & Vietnamese teachers & 28 & 14.89 & .92 & .17 & 14.54 & 15.25 & 13.00 & 17.00 \\
\hline & Filipino teachers & 26 & 15.85 & 1.01 & .20 & 15.44 & 16.25 & 14.00 & 18.00 \\
\hline & Native English teachers & 26 & 15.73 & .92 & .18 & 15.36 & 16.10 & 14.00 & 17.00 \\
\hline & Total & 80 & 15.48 & 1.03 & .12 & 15.25 & 15.70 & 13.00 & 18.00 \\
\hline \multirow[t]{4}{*}{$\mathrm{L}$} & Vietnamese teachers & 28 & 19.89 & 1.26 & .24 & 19.41 & 20.38 & 17.00 & 22.00 \\
\hline & Filipino teachers & 26 & 19.69 & 1.12 & .22 & 19.24 & 20.15 & 17.00 & 21.00 \\
\hline & Native English teachers & 26 & 26.15 & .92 & .18 & 25.78 & 26.53 & 24.00 & 28.00 \\
\hline & Total & 80 & 21.86 & 3.19 & .36 & 21.15 & 22.57 & 17.00 & 28.00 \\
\hline \multirow[t]{4}{*}{ Total } & Vietnamese teachers & 28 & 13.19 & .41 & .08 & 13.03 & 13.35 & 12.20 & 14.00 \\
\hline & Filipino teachers & 26 & 13.02 & .50 & .10 & 12.82 & 13.23 & 11.60 & 14.00 \\
\hline & Native English teachers & 26 & 16.58 & .49 & .10 & 16.38 & 16.78 & 15.60 & 17.40 \\
\hline & Total & 80 & 14.24 & 1.70 & .19 & 13.86 & 14.62 & 11.60 & 17.40 \\
\hline
\end{tabular}

TABLE 4. Results of One-Way ANOVA comparing the use of cohesive devices across three groups

\begin{tabular}{|c|c|c|c|c|c|c|}
\hline & \multirow[t]{2}{*}{ (I) Nationality } & \multirow[t]{2}{*}{ (J) Nationality } & \multirow{2}{*}{$\begin{array}{r}\text { Difference } \\
\text { (I-J) }\end{array}$} & \multirow[t]{2}{*}{ Sig. } & \multicolumn{2}{|c|}{ 95\% Confidence Interval } \\
\hline & & & & & Lower Bound & Upper Bound \\
\hline \multirow[t]{4}{*}{$\mathrm{R}$} & \multirow[t]{2}{*}{ Vietnamese teachers } & Filipino teachers & $.83^{*}$ & .007 & .24 & 1.43 \\
\hline & & Native English teachers & $-3.82^{*}$ & .000 & -4.41 & -3.23 \\
\hline & \multirow[t]{2}{*}{ Filipino teachers } & Vietnamese teachers & $-.83^{*}$ & .007 & -1.43 & -.24 \\
\hline & & Native English teachers & $-4.65^{*}$ & .000 & -5.26 & -4.05 \\
\hline \multirow[t]{4}{*}{ S } & \multirow[t]{2}{*}{ Vietnamese teachers } & Filipino teachers & -.49 & .065 & -1.00 & .03 \\
\hline & & Native English teachers & $-2.60^{*}$ & .000 & -3.12 & -2.08 \\
\hline & \multirow[t]{2}{*}{ Filipino teachers } & Vietnamese teachers & .49 & .065 & -.03 & 1.00 \\
\hline & & Native English teachers & $-2.12^{*}$ & .000 & -2.64 & -1.59 \\
\hline \multirow[t]{4}{*}{$\mathrm{E}$} & \multirow[t]{2}{*}{ Vietnamese teachers } & Filipino teachers & $1.26^{*}$ & .000 & .77 & 1.74 \\
\hline & & Native English teachers & $-3.40^{*}$ & .000 & -3.89 & -2.91 \\
\hline & \multirow[t]{2}{*}{ Filipino teachers } & Vietnamese teachers & $-1.26^{*}$ & .000 & -1.74 & -.77 \\
\hline & & Native English teachers & $-4.66^{*}$ & .000 & -5.15 & -4.16 \\
\hline \multirow[t]{4}{*}{$\mathrm{C}$} & \multirow[t]{2}{*}{ Vietnamese teachers } & Filipino teachers & $-.95^{*}$ & .000 & -1.47 & -.44 \\
\hline & & Native English teachers & $-.84^{*}$ & .002 & -1.35 & -.32 \\
\hline & \multirow[t]{2}{*}{ Filipino teachers } & Vietnamese teachers & $.95^{*}$ & .000 & .44 & 1.47 \\
\hline & & Native English teachers & .12 & .662 & -.41 & .64 \\
\hline \multirow[t]{4}{*}{$\mathrm{L}$} & \multirow[t]{2}{*}{ Vietnamese teachers } & Filipino teachers & .20 & .511 & -.40 & .80 \\
\hline & & Native English teachers & $-6.26^{*}$ & .000 & -6.87 & -5.66 \\
\hline & \multirow[t]{2}{*}{ Filipino teachers } & Vietnamese teachers & -.20 & .511 & -.80 & .40 \\
\hline & & Native English teachers & $-6.46^{*}$ & .000 & -7.08 & -5.85 \\
\hline \multirow[t]{4}{*}{ Total } & \multirow[t]{2}{*}{ Vietnamese teachers } & Filipino teachers & .17 & .188 & -.08 & .42 \\
\hline & & Native English teachers & $-3.38^{*}$ & .000 & -3.64 & -3.13 \\
\hline & \multirow[t]{2}{*}{ Filipino teachers } & Vietnamese teachers & -.17 & 188 & .42 & -.08 \\
\hline & & Native English teachers & $-3.55^{*}$ & .000 & -3.81 & -3.29 \\
\hline
\end{tabular}


The statistics achieved from One-Way ANOVA compared the use of cohesive instances by the Vietnamese, Filipino, and native English teachers. Some trends were identified from the multiple comparisons (see Table 4). First, the mean difference in the number of references, substitutions, conjunctions, and lexical cohesion devices between the Vietnamese and Filipino groups was lower than 1.0. Also, the Vietnamese EFL teachers significantly used more cohesive devices of reference and ellipsis than the Filipino ones $(p<$ $.01)$. Although the Filipinos used more substitution devices than the Vietnamese ones, the mean difference was insignificant $(p>.05)$. The Filipino EFL teachers significantly used more conjunctions than the Vietnamese counterparts $(p<.01)$. Overall, there were some discrepancies in the number of cohesive devices used by these two groups of teachers. Although the native English teachers generally used significantly more devices in each subclass $(p<.01)$, it was the conjunction that this difference between the Filipino and the native English teachers was insignificant $(p>.05)$.

\section{RESEARCH QUESTION 2: WHAT TYPES OF COHESION ERRORS DO VIETNAMESE AND FILIPINO EFL TEACHERS MAKE IN WRITING?}

Analysis of the errors made by the Vietnamese and Filipino EFL teachers showed that they did not make any errors in the use of ellipsis. The average number of errors each participant made ranged from 2.45 to 2.85 (see Table 5). Most errors fell into the categories of reference, connectives, and lexical cohesion. While the mean score of errors in the use of substitution made by the Vietnamese teachers was relatively insignificant $(M=.11)$, the Filipinos made no errors of this type. A comparison with the participants' use of this word class (see Tables 3 and 4) showed that the error patterns the participants made generally coincided with the cohesion patterns they used.

TABLE 5. Errors across different categories made by Vietnamese and Filipino teachers

\begin{tabular}{llcccc}
\hline & Nationality & N & Mean & SD & SD Error Mean \\
\hline RE & Vietnamese teachers & 28 & 3.57 & .74 & .14 \\
& Filipino teachers & 26 & 3.73 & .87 & .17 \\
SU & Vietnamese teachers & 28 & .11 & .31 & .06 \\
& Filipino teachers & 26 & .00 & .00 & .00 \\
& Vietnamese teachers & 28 & 2.82 & .72 & .14 \\
& Filipino teachers & 26 & 3.08 & .80 & .16 \\
& Vietnamese teachers & 28 & 3.29 & .81 & .15 \\
\multirow{2}{*}{ Total } & Filipino teachers & 26 & 4.04 & .92 & .18 \\
& Vietnamese teachers & 28 & 2.45 & .33 & .06 \\
& Filipino teachers & 26 & 2.71 & .32 & .06 \\
\hline
\end{tabular}

TABLE 6. Results of Independent-Sample T-Test comparing the errors across categories

\begin{tabular}{|c|c|c|c|c|c|c|c|c|c|}
\hline & \multirow[b]{2}{*}{ Sig. } & \multirow[b]{2}{*}{$\mathbf{t}$} & \multirow[b]{2}{*}{ df } & \multirow{2}{*}{$\begin{array}{c}\text { Sig. } \\
\text { (2-tailed) }\end{array}$} & \multirow{2}{*}{$\begin{array}{c}\text { Mean } \\
\text { Difference }\end{array}$} & \multirow{2}{*}{$\begin{array}{l}\text { SD Error } \\
\text { Difference }\end{array}$} & \multicolumn{2}{|c|}{ 95\% Confidence } \\
\hline & & & & & & & & Lower & Upper \\
\hline \multirow[t]{2}{*}{$\mathrm{RE}$} & Equal variances assumed & .274 & -.724 & 52 & .472 & -.15934 & .22014 & -.60108 & .28240 \\
\hline & Equal variances not assumed & & -.719 & 49.224 & .475 & 5934 & 150 & -.60 & .28572 \\
\hline \multirow[t]{2}{*}{ SU } & Equal variances assumed & .000 & 1.733 & 52 & .089 & & & & .23118 \\
\hline & ces not assumed & & 1.800 & 27.000 & .083 & & & & .22928 \\
\hline \multirow[t]{2}{*}{$\mathrm{CO}$} & Equal variances as & .658 & -1.236 & 52 & .222 & -.2 & & & 929 \\
\hline & Equal variances nc & & -1.232 & 50.515 & .224 & & & & 109 \\
\hline \multirow[t]{2}{*}{$\mathrm{LC}$} & Equal variances assumed & .916 & -3.205 & 52 & .002 & -.75275 & .23488 & -1.22407 & -.28142 \\
\hline & Equal $v$ & & -3.190 & 50.058 & .002 & & & -1.22669 & -.27881 \\
\hline \multirow[t]{2}{*}{ Total } & Equal variances a & .942 & -2.991 & 52 & .004 & -.26 & .08862 & -.44295 & -.08727 \\
\hline & Equal variances not assumed & & -2.994 & 51.852 & .004 & -.26511 & .08855 & -.44281 & -.08741 \\
\hline
\end{tabular}


Results from the Independent-Samples T-Test showed a breakdown of errors made by the Vietnamese and Filipino EFL teachers across four out of the five sub-classes: RE (reference), SU (substitution), CO (conjunction), and LC (lexical cohesion) as shown in Table 6. Ellipsis errors were not evident in the teachers' monthly reports. Surprisingly, although reference, conjunction, and lexical cohesion were the sub-classes these participants used the most, significant differences were only found in the sub-classes of conjunction and lexical cohesion.

Table 7 shows four main types of errors identified in the Vietnamese and Filipino teachers' written reports, namely misuse (MU), redundancy (RD), omission (OM), and overabundance (OA). Overall, while most Vietnamese teachers' errors were the omission of cohesive devices, a majority of errors made by the Filipino counterparts lied with redundancy and omission. On the other hand, each group's overuse of devices only accounted for a minor proportion. Both Vietnamese and Filipino EFL teachers made small proportions of errors in using demonstrative, temporal, hyponymy, and meronymy.

TABLE 7. Types of errors

\begin{tabular}{|c|c|c|c|c|c|c|c|c|}
\hline \multirow[t]{2}{*}{ Type } & \multirow[t]{2}{*}{ Sub-type } & \multicolumn{7}{|c|}{ Vietnamese } \\
\hline & & MU & & RD & \multirow{2}{*}{\multicolumn{2}{|c|}{$\begin{array}{c}\text { OM } \\
19(59.37 \%)\end{array}$}} & \multicolumn{2}{|r|}{$\mathbf{O A}$} \\
\hline \multirow[t]{4}{*}{$\mathrm{RE}$} & Definite article & $8(25.00 \%)$ & & $(9.38 \%)$ & & & \multicolumn{2}{|c|}{$2 \quad(6.25 \%)$} \\
\hline & Pronominal & $11(36.67 \%)$ & & $(13.33 \%)$ & \multicolumn{2}{|c|}{$12(40.00 \%)$} & \multicolumn{2}{|c|}{$3(10.00 \%)$} \\
\hline & Comparative & $9(33.33 \%)$ & & $(18.52 \%)$ & \multicolumn{2}{|c|}{$10(37.04 \%)$} & \multicolumn{2}{|c|}{$3(11.11 \%)$} \\
\hline & Demonstrative & $6(54.55 \%)$ & 0 & $(0 \%)$ & \multicolumn{2}{|c|}{$4(36.36 \%)$} & \multicolumn{2}{|c|}{$1 \quad(9.09 \%)$} \\
\hline \multirow[t]{4}{*}{$\mathrm{CO}$} & Additive & $6(16.67 \%)$ & 9 & $(25.00 \%)$ & \multicolumn{2}{|c|}{$19(52.78 \%)$} & \multicolumn{2}{|c|}{$2(5.55 \%)$} \\
\hline & Adversative & $2(10.53 \%)$ & 7 & $(36.84 \%)$ & \multicolumn{2}{|c|}{$9(47.37 \%)$} & \multicolumn{2}{|c|}{$1(5.26 \%)$} \\
\hline & Causal & $6(37.50 \%)$ & 4 & $(25.00 \%)$ & \multicolumn{2}{|c|}{$6(37.50 \%)$} & \multicolumn{2}{|c|}{$0(0 \%)$} \\
\hline & Temporal & $3(37.5 \%)$ & 1 & $(12.50 \%)$ & \multicolumn{2}{|c|}{$4(50 \%)$} & \multicolumn{2}{|c|}{$0(0 \%)$} \\
\hline \multirow[t]{4}{*}{$\mathrm{LC}$} & Synonymy & $6(15.38 \%)$ & 15 & $(38.46 \%)$ & \multicolumn{2}{|c|}{$2(5.13 \%)$} & \multicolumn{2}{|c|}{$16(41.03 \%)$} \\
\hline & Repetition & $9(21.95 \%)$ & 9 & $(21.95 \%)$ & \multicolumn{2}{|c|}{$0(0 \%)$} & \multicolumn{2}{|c|}{$23(56.1 \%)$} \\
\hline & Hyponymy & $1(14.29 \%)$ & & $(28.57 \%)$ & \multicolumn{2}{|c|}{$3(42.85 \%)$} & \multicolumn{2}{|c|}{$1(14.29 \%)$} \\
\hline & Meronymy & $1(20 \%)$ & \multicolumn{2}{|c|}{$2(40.00 \%)$} & \multicolumn{2}{|c|}{$2(40 \%)$} & 0( & $\%)$ \\
\hline & & & & & pino & & & \\
\hline Type & Sub-type & $\mathbf{M U}$ & & RD & O & & & $\mathbf{A}$ \\
\hline $\mathrm{RE}$ & Definite article & $9(29.03 \%)$ & 14 & $(3.22 \%)$ & 21 & $(67.74 \%)$ & 0 & $(0 \%)$ \\
\hline & Pronominal & $8 \quad(25.81 \%)$ & 5 & $(16.13 \%)$ & 13 & $(41.93 \%)$ & 5 & $(16.13 \%)$ \\
\hline & Comparative & $4 \quad(18.18 \%)$ & 0 & $(0 \%)$ & 8 & $(36.36 \%)$ & 10 & $(45.46 \%)$ \\
\hline & Demonstrative & $7 \quad(47.37 \%)$ & 3 & $(26.32 \%)$ & 2 & $(15.79 \%)$ & 1 & $(10.53 \%)$ \\
\hline $\mathrm{CO}$ & Additive & $6(11.9 \%)$ & 32 & $(52.38 \%)$ & 9 & $(21.43 \%)$ & 6 & $(14.29 \%)$ \\
\hline & Adversative & $4 \quad(14.29 \%)$ & 13 & $(46.43 \%)$ & 7 & $(25 \%)$ & 4 & $(14.29 \%)$ \\
\hline & Causal & $7 \quad(26.92 \%)$ & 0 & $(34.62 \%)$ & 10 & $(38.46 \%)$ & 1 & $(0 \%)$ \\
\hline & Temporal & $3 \quad(22.22 \%)$ & 1 & $(55.56 \%)$ & 4 & $(22.22 \%)$ & 0 & $(0 \%)$ \\
\hline LE & Synonymy & 9 (28.13\%) & 5 & $(15.62 \%)$ & 6 & $(18.75 \%)$ & 12 & $(37.50 \%)$ \\
\hline & Repetition & $8 \quad(20.51 \%)$ & 12 & $(30.77 \%)$ & 4 & $(10.26 \%)$ & 15 & $(38.46 \%)$ \\
\hline & Hyponymy & $5 \quad(23.81 \%)$ & 8 & $(38.10 \%)$ & 5 & $(23.81 \%)$ & 3 & $(14.28 \%)$ \\
\hline & Meronymy & $2(15.38 \%)$ & 3 & $(23.08 \%)$ & 8 & $(61.54 \%)$ & 0 & $(0 \%)$ \\
\hline
\end{tabular}

\section{DISCUSSION}

The study investigated the use of cohesive devices in written reports by two groups of nonnative English speakers (Vietnamese and Filipino EFL teachers) and one group of native English speakers having a teaching position in Vietnam. Generally, the sub-categories the participants mainly employed and the error patterns identified in their reports varied significantly. The difference in using cohesion signals between the Vietnamese EFL teachers $(\mathrm{M}=13.19)$ and Filipino EFL teachers $(\mathrm{M}=13.02)$ was insignificant $(p>.05)$. However, the native English teachers appeared to use far more cohesive devices than the other two groups ( $p$ $<.01)$. Also, the cohesive devices used by the native English teachers were more diverse, but 
these instances used by the Vietnamese and Filipino teachers mainly focused on the three main sub-classes: reference, conjunction, and lexical cohesion (see Tables 3 and 4). This finding aligns with previous research in which Rahman (2013) found that native English speakers used cohesive devices more frequently than speakers of English as a second or foreign language. Our finding is also consistent with Mojica's (2006) study, which revealed that Filipino ESL speakers used cohesive lexical indices in writing most frequently of all the sub-classes.

Given the main focus of the current study on the use of cohesive devices by Vietnamese and Filipino teachers in writing their monthly reports, the results pertaining to these two groups of participants deserve a more detailed discussion. Further analysis of the participants' use of the sub-classes indicated that the Vietnamese teachers used significantly more cohesive instances than the Filipinos in terms of reference and ellipsis. The use of conjunctions by the Filipinos significantly outnumbered that by the Vietnamese counterparts $(p<.01)$. However, the differences in the use of substitution and lexical cohesion between these two groups were statistically insignificant.

The study has also found that language proficiency did not determine the frequency of cohesive connectors used in the participants' written texts. Our findings indicate that the relationship between language proficiency and the use of cohesive devices was not strong. While the Vietnamese and Philipino teachers were at a comparably similar level of English proficiency (C1 level of the CEFR), the cohesive instances used in the Vietnamese and Filipino EFL teachers' writing varied significantly across the sub-classes. This suggests that non-native English speakers of the same proficiency level may differ in their use of textual cohesion devices. This finding confirms previous studies by Crossley et al. (2007) and Crosley and McNamara (2012). The study findings suggest that language proficiency cannot predict all the linguistic features L2 speakers use in their writing but only indicates their general performance (Segalowitz, 2010, 2016). As such, it is important that researchers collect L1 and L2 data to determine the speakers' fluency in using a specific language aspect.

One underlying factor accounting for the difference in text cohesion is the nature of each group's written reports. Analysis of the monthly reports by the three groups of participants showed that most of the native English speakers wrote their reports in an argumentative manner, including both description and reflection-on-action sections. In contrast, the Vietnamese and Filipino teachers generally described their situations rather than justifying or explaining any causal relationship. Without taking text quality and writing styles into consideration, the data showed that the non-native English speakers did not use as many cohesive devices to link their ideas as the native English speakers. According to Berzlánovich et al. (2012), text cohesion may be affected by how a text is structured and what genre is employed. In our study, while the native English speakers' reports included a wide range of sub-categories of cohesive devices, the Vietnamese and Filipino teachers mainly used three out of five sub-classes in the taxonomy. The Vietnamese and Filipino teachers repeated lexical items more frequently than the native speakers. It could be the native English speakers' wider vocabulary repertoire that allowed them to avoid repeating vocabulary use. As ESL/EFL speakers have a smaller range of lexical resources than native English speakers, they tend to rely on repetition as a means to link their ideas within a written text (Ong, 2011). Also, since Asian speakers are not equally exposed to different kinds of cohesive devices in English, the lexical overlap in their use of such cohesive devices is more likely to emerge (Yang \& Sun, 2012). Rahman (2013) has also argued that L2 speakers' knowledge of writing genre, writing styles, frequency of regular practice, and understanding of the target readers' interest have an impact on their use of cohesion patterns.

With regard to the second research question, the study has found that the Vietnamese and Filipino teachers virtually shared the same patterns of errors in using cohesive devices (see Tables 5 and 7). This finding aligns with the results of Ong's (2011) study, which showed that 
non-native English speakers did not usually overuse indices of cohesion. Furthermore, the Vietnamese and Filipino teachers did not demonstrate any major problems in using ellipsis and substitution. This phenomenon is consistent with previous research in which Yang and Sun (2012) found that the use of ellipsis and substitution in writing was not a challenge for Chinese EFL students. However, this trend did not mean the Vietnamese and Filipino teachers were more proficient in using these sub-categories. Research has shown that L2 speakers tend to avoid using the language elements they are not sure about in language production (Crossley et al., 2016; De Jong et al., 2012; Rahman, 2013). A close comparison of the statistics presented in Tables 3 and 5 showed that the number of cohesion instances and errors of ellipsis and substitution identified in the Vietnamese and Filipino teachers' reports accounted for smaller percentages than those of the other sub-classes. Also, while the Vietnamese teachers omitted many cohesive devices, the Filipino counterparts' errors mostly related to redundancy. In writing their reports, the Vietnamese teachers mainly used definite articles, additives, and synonyms and made most errors in these categories. Paradoxically, although the Filipinos made a majority of errors in the same categories, the error pattern was quite different. This paradoxical observation indicates that familiarity with specific groups of cohesive devices in part determines the extent to which ESL/EFL speakers can use them efficiently in their writing (Rahman, 2013). From the perspective of second language acquisition theories, if L2 learners use specific language items unconsciously, their errors are more likely to occur (Han, 2004).

One of the main contributions of the current study is that it introduced a cross-linguistic approach to analysing L2 speakers' use of cohesive devices. The variation in the use of and problems with cohesive devices in writing reflected the writers' cognitive-social background (Castro, 2004, Solnyshkina et al., 2020). As this study used a cross-linguistic model developed by Jarvis (2000), most major variables between the two groups of participants (Vietnamese and Filipino) were controlled. Jarvis (2000) suggested that a cross-linguistic model can help researchers gain in-depth understandings of the influence of L1 in the use of L2.

The study has pedagogical implications for promoting ESL/EFL writers' effective use of cohesive devices in their writing process. First, to increase the cohesion and range of lexical resources in their writing, it might be helpful for ESL/EFL writers to diversify their use of subtypes of cohesive connectors. Al-Khasawneh (2019) and Lee and Wong (2020) hold that L2 learners' vocabulary inventory has a great impact on their receptive skills. For this reason, knowledge of cohesive devices and practice is of paramount importance. Second, living in contexts in which English is used as a second or foreign language, ESL/EFL writers may find it disadvantageous to operate efficiently. Thus, good knowledge of rhetorical, stylistic, and cultural differences between the L2 speaker's culture and the culture of the target language may bridge the gap in cohesion between native and non-native speakers (Clouet, 2017). This means non-native English speakers need to be exposed to texts by native English speakers to improve their repertoire of cohesive indices. Additionally, it might be useful for coursebooks and dictionaries to include these aspects of cohesive devices so as for learners to enhance the efficacy of their language use. Finally, the practice of teaching English grammar at the sentence level may not guarantee ESL/EFL learners' success in producing highly cohesive texts. Instruction on text organisation and development in which ideas are cohesively woven is therefore necessary (Hirvela, 2004; Srisang \& Everatt, 2021; Tahir et al., 2020).

A possible limitation of our research lies in its capacity to generalise the study findings for several reasons. First, as the study results were obtained from 80 EFL teachers teaching at five English centres in South Vietnam, it is unlikely that generalisability can be made about how Vietnamese and Filipino EFL teachers use cohesive devices in their writing. Second, given that L1 data were not collected, the study did not provide any insight into the participants' L1 interference in their use of L2. Finally, we acknowledge that the participants could have 
avoided using the language items they were unfamiliar with; thus, errors of several cohesive devices may not have been evident in their monthly reports.

\section{CONCLUSION}

Consistent with previous research, the current study confirmed the low usage of cohesive devices among Asian ESL/EFL speakers compared to native English speakers. A similar distribution of cohesion patterns and errors among Vietnamese and Filipino speakers of English was also identified in this study. An interesting finding of the current study is that the Vietnamese and Filipino EFL teachers who were at a comparable level of English proficiency shared a general pattern of cohesion indicators in use but differed in terms of errors. The study suggests that language proficiency is not the only factor influencing L2 use and error patterns of cohesive devices.

Further research could focus on other regions of Asia to generalise cohesion errors and patterns by ESL/EFL speakers or on L2 speakers' use of this word class in oral communication. It would also be interesting to see what variables moderate or mediate L2 writers' ability to use cohesive devices and how they overcome cohesion-related problems. From a social-linguistic perspective, it may be helpful for research to examine the effects of language varieties on the use of cohesive devices. The effects of global and localised coursebooks on learners' ability to control cohesion, coherence, and text unity also merit further exploration.

\section{ACKNOWLEDGEMENT}

The authors would like to thank the teachers at the five English centres where data was collected. This work was funded by University of Economics Ho Chi Minh City, Vietnam.

\section{REFERENCES}

Al-Jarf, R. S. (2001). Processing of cohesive ties by EFL Arab college. Foreign Language Annals. 34, 141-151. https://doi.org/10.1111/j.1944-9720.2001.tbo2819.x

Al-Khasawneh, F. (2019). The Impact of Vocabulary Knowledge on the Reading Comprehension of Saudi EFL Learners. Journal of Language and Education. 5(3), 24-34. https://doi.org/10.17323/jle.2019.8822

Berzlánovich, I., Egg, M. \& Egg, M. (2012). Coherence structure and lexical cohesion in expository and persuasive texts. In Benz, A., Stede, M. \& Kühnlein, P. (Eds.). Constraints in Discourse 3: Representing and inferring discourse structure (pp. 137-164). Amsterdam: John Benjamins Publishing Company. https://doi.org/10.1075/pbns.223.06ber

Castro, C. (2004) Cohesion and the social construction of meaning in the essays of Filipino college students writing in L2 English. Asia Pacific Journal of Education. 5, 215-225.

Clouet, R. (2017). The intercultural dimension of English as an academic lingua franca (EALF) in scientific publications. Revista de Lenguas para Fines Especificos. 23(2), 313-333. http://dx.doi.org/10.20420/rlfe.2017.184

Collins, P. \& Hollo, C. (2010). English grammar. London: Palgrave Macmillan.

Cox, B. E., Shanahan, T. \& Sulzby, E. (1990). Good and poor elementary readers' use of cohesion in writing. Research Quarterly. 15, 47-65.

Crossley, S. A. \& McNamara, D. S. (2012). Predicting second language writing proficiency: The roles of cohesion and linguistic sophistication. Journal of Research in Reading. 35 (2), 115-135. https://doi.org/10.1111/j.1467-9817.2010.01449.x

Crossley, S. A., Kyle, K. \& McNamara, D. S. (2016). The development and use of cohesive devices in L2 writing and their relations to judgments of essay quality. Journal of Second Language Writing. 32, 1-16. https://doi/org/10.1016/j.jslw.2016.01.003

Crossley, S. A., Louwerse, M. M., Mccarthy, P. M. \& McNamara, D. (2007). A linguistic analysis of simplified and authentic texts. The Modern Language Journal. 91(1), 15-30. https://doi.org/10.1111/j.15404781.2007.00507.x 
Chiang, S. Y. (1999). Assessing grammatical and textual features in L2 writing samples: The case of French as a foreign language. The Modern Language Journal. 83(2), 219-232. https://doi.org/10.1111/00267902.00017

De Jong, N. H., Steinel, M. P., Florijn, A., Schoonen, R. \& Hulstijn, J. H. (2012). Linguistic skills and speaking fluency in a second language. Applied Psycholinguistics. 34(5), 893-916. https://doi.org/10.1017/S0142716412000069

Enkvist, N. E. (1990). Seven problems in the study of coherence and interpretability. In Connor, U. \& Johns, A. M. (Eds.). Coherence in writing: Research and pedagogical perspectives (pp. 9-28). Alexandria: Teachers of English to Speakers of Other Languages.

Farsani, M. A., Abdollahzadeh, E. \& Beikmohammadi, M. (2019). Self-regulated learning, metacognitive awareness, and argumentative writing: A structural equation modelling approach. Writing and Pedagogy. 11(2), 195-222. https://doi.org/10.1558/wap.37051

Halliday, M. K. \& Hasan, R. (1976). Cohesion in English. London: Longman.

Halliday, M. K. \& Matthiessen, M. M. (2014). Halliday's introduction to functional grammar. London: Routledge.

Hammad, E. (2016). Palestinian university students' problems with EFL essay writing in an instructional setting. In Ahmed, A. \& Abouabdelkader, H. (Eds.). Teaching EFL Writing in the 21st Century Arab World (pp. 99-120). London: Palgrave Macmillan. https://doi.org/10.1057/978-1-137-46726-3 5

Han, Z. (2004). Fossilisation: five central issues. International Journal of Applied Linguistics. 14(2), $212-242$. https://doi.org/ 10.1111/j.1473-4192.2004.00060.x

Hirvela, A. (2004). Connecting reading and writing in second language writing instruction. Ann Arbor: University of Michigan Press.

Hoa, C. T. H. (2020). Integrating culture into teaching EFL in general education: A context of Vietnam. Language Related Research. 11(5), 227-252. https://doi.org/10.21859/LRR.11.5.227

IELTS (2019). Test taker performance 2018. Retrieved from https://www.ielts.org/teaching-and-research/testtaker-performance.

Jarvis, S. (2000). Methodological rigour in the study of transfer: Identifying L1 influence in the interlanguage lexicon. Language Learning. 50(2), 245-309. https://doi.org/10.1111/0023-8333.00118

Johns, A. M. (1986). Coherence and academic writing: some definitions and suggestions for teaching. TESOL Quarterly, 20(2), 247-266. https://doi.org/10.2307/3586543C

Kang, J. Y. (2005). Written narratives as an index of L2 competence in Korean EFL learners. The Journal of Second Language Writing. 14(4), 259-279. https://doi.org/10.1016/j.jslw.2005.10.002

Koshik, I. (1999). A preliminary investigation into the effect of grammatical cohesive devices: Their absence and their misuse on the comprehension of non-native speaker speech and writing. Issues in Applied Linguistics. 10(1), 3-25.

Lake, J. (2004). Using “on the contrary": the conceptual problem for EAP students. ELT Journal. 58(2), 137-144. https://doi.rog/10.1093/elt/58.2.137

Le, T. T. H. \& Phan, L. H. (2013). Problematising the culture of learning English in Vietnam: Revisiting teacher identity. In Cortazzi, M. \& Jin, L. (Eds.). Researching cultures of learning. London: Palgrave Macmillan. https://doi.org/10.1057/9781137296344_13

Lee, J. Y. V. \& Wong, A. S. C. (2020). Vocabulary size and critical academic reading ability of secondary students in Sabah. 3L: Language, Linguistics, Literature. 26(4), 15-27. http://doi.org/10.17576/3L-2020-2604-02

Liu, M. \& Braine, G. (2005). Cohesive features in argumentative writing. System. 33, 623-636. https://doi.org/ 10.1016/j.system.2005.02.002

Mackey, A. \& Gass, S. M. (2005). Second language research: Methodology and design. Mahwah: Lawrence Erlbaum Associates Publishers.

Malmkjaer, K. (2001). The linguistic encyclopedia. London: Routledge.

MOET (2008). Project on teaching and learning English in the period of 2008-2020 (Quyết định số 1400/QĐ-TTG của Thủ tương Chính phủ : Về việc phê duyệt Đề án "Dạy và học ngoại ngũ trong hệ thống giáo duc quốc $\begin{array}{llll}\text { dân giai doạn } 2008 \quad- & \left.2020^{\prime \prime}\right) .\end{array}$ http://chinhphu.vn/portal/page/portal/chinhphu/hethongvanban?class_id=1\&_page=18\&mode=detail\&d ocument id $=78437$

Normant, N. (2002). Quantitative and qualitative analysis of textual cohesion in African American students writing in narrative, argumentative, and expository modes. CLA Journal. 46, 1-98.

Nunan, D. (1989). Designing tasks for the communicative classroom. Cambridge: Cambridge University Press.

Oller, J. W. \& Jonz, J. (1994). Cloze and coherence. Cranbury: Associated University Presses

Ong, J. (2011). Investigating the use of cohesive devices by Chinese EFL learners. Asian EFL Journal. 13(3), 4265.

Rahman, Z. A. (2013). The use of cohesive devices in descriptive writing by Omani student teachers. Sage Open. 3(4), 1-10. https://doi.org/10.1177/2158244013506715 
Reynolds, D. W. (2001). Language in the balance: Lexical repetition as a function topic, cultural background, and writing development. Language Learning. 51(3), 437-476. https://doi.org/10.1111/0023-8333.00161

Sanders, T. \& Maat, H. (2006). Cohesion and coherence: Linguistic approaches. In Brown, K. Encyclopedia of Language and Linguistics (pp. 39-54). Amsterdam: Elsevier.

Segalowitz, N. (2010). Cognitive bases of second language fluency. New York: Routledge

Segalowitz, N. (2016). Second language fluency and its underlying cognitive and social determinants. International Review of Applied Linguistics in Language Teaching. 54(2), 79-95. https://doi.org/ 10.1515/iral-2016-9991

Solnyshkina, M. I., Harkova, E. V. \& Kazachkova, M. B. (2020). The Structure of Cross-Linguistic Differences: Meaning and Context of 'Readability' and its Russian Equivalent' Chitabelnost'. Journal of Language and Education. 6(1), 103-119. https://doi.org/10.17323/jle.2020.7176

Srisang, P. \& Everatt, J. (2021). Lower and higher level comprehension skills of undergraduate EFL learners and their reading comprehension. LEARN Journal: Language Education and Acquisition Research Network. 14(1), 427-454.

Taboada, M. T. (2004). Building coherence and cohesion: Task-oriented dialogue in English and Spanish. Amsterdam: John Benjamins Publishing.

Tahir, M. H.M., Albakri, I. S. M. A., Adnan, A. H. M. \& Karim, R. A. (2020). The effects of explicit vocabulary instructions on secondary ESL students' vocabulary learning. 3L: Language, Linguistics, Literature. 26(2), 158-172. http://doi.org/10.17576/3L-2020-2602-12

Tanskanen, S. K. (2006). Collaborating towards coherence: Lexical. Amsterdam: John Benjamins.

Todd, R. W., Khongput, S. \& Darasawang, P. (2007). Coherence, cohesion and comments on students' academic essays. Assessing Writing. 12(1), 10-25. https://doi.org/10.1016/i.asw/2007.02.002

Tomlinson, B. \& Dat, B. (2004). The contributions of Vietnamese learners of English to ELT methodology. Language Teaching Research. 8(2), 199-222. https://doi.org/10.1191/13621688041r140oa

Yang, W. \& Sun, Y. (2012). The use of cohesive devices in argumentative writing by Chinese EFL learners at different proficiency levels. Linguistics and Education. 23(1), 31-48. https://doi.org/ 10.1016/j.linged.2011.09.004

Yin, Z. (2015). The use of cohesive devices in news language: overuse, underuse or misuse? RELC Journal. 46(3), 309-326. https://doi.org/10.1177/0033688215597578

Yule, G. (2008). The study of language (3rd ed.). New Delhi: Cambridge University Press.

Zhang, M. (2000). Cohesive features in the expository writing of undergraduates in two Chinese universities. RELC Journal. 31(1), 61-95. https://doi.org/10.1177/003368820003100104 